\title{
Chiral bisoxazoline ligands designed to stabilize bimetallic complexes
}

\author{
Deepankar Das ${ }^{1}$, Rudrajit Mal ${ }^{1}$, Nisha Mittal ${ }^{1}$, Zhengbo Zhu $^{2}$, Thomas J. Emge ${ }^{1}$ \\ and Daniel Seidel ${ }^{* 1,2}$
}

\author{
Full Research Paper \\ Address: \\ ${ }^{1}$ Department of Chemistry and Chemical Biology, Rutgers, The State \\ University of New Jersey, Piscataway, NJ 08854, USA and ${ }^{2}$ Center \\ for Heterocyclic Compounds, Department of Chemistry, University of \\ Florida, Gainesville, Florida 32611, USA \\ Email: \\ Daniel Seidel ${ }^{\star}$ - seidel@chem.ufl.edu \\ * Corresponding author \\ Keywords: \\ bimetallic complexes; bisoxazolines; chiral ligands; heterocycles
}

\author{
Beilstein J. Org. Chem. 2018, 14, 2002-2011. \\ doi:10.3762/bjoc. 14.175 \\ Received: 28 May 2018 \\ Accepted: 12 July 2018 \\ Published: 01 August 2018 \\ Associate Editor: L. Ackermann \\ (c) 2018 Das et al.; licensee Beilstein-Institut. \\ License and terms: see end of document.
}

\begin{abstract}
Chiral bisoxazoline ligands containing naphthyridine, pyridazine, pyrazole, and phenol bridging units were prepared and shown to form bimetallic complexes with various metal salts. X-ray crystal structures of bis-nickel naphthyridine-bridged, bis-zinc pyridazine-bridged, and bis-nickel as well as bis-palladium pyrazole-bridged complexes were obtained.
\end{abstract}

\section{Introduction}

Metal-centered asymmetric catalysis most commonly relies on monometallic complexes of various chiral ligands, among which chiral bisoxazolines have been highly successful in facilitating various Lewis acid-catalyzed asymmetric transformations [1-3]. In addition to monometallic catalysis, it has long been recognized that catalysts possessing two or more metal centers in close proximity can be uniquely effective in catalyzing certain types of reactions [4-6]. Serving as a main source of inspiration in the design of chiral small-molecule systems, nature utilizes a variety of bimetallic and multimetallic protein complexes to perform a host of biological functions [7]. Urease [8], hemerythrin [9], methane monooxygenase [10], ribonucleotide reductase [11], catechol oxidase [12], and arginase [13], are prominent examples of such bimetallic enzymes.

A range of bi- and multi-metallic complexes have been utilized in asymmetric catalysis (Figure 1) [6]. For instance, Shibasaki and co-workers introduced a number of chiral multi-metallic complexes such as the hetero-bimetallic complex 1, in which the two different metals play distinct roles $[14,15]$. Jacobsen and co-workers reported dimeric salen complexes 2 which show cooperative reactivity between the two metal centers in the asymmetric ring opening of meso-epoxides [16]. Trost et al. disclosed the synthesis of dinuclear zinc complexes $\mathbf{3}$ and their application to enantioselective Aldol reactions [17,18] and a 
host of other asymmetric transformations [18]. Other notable contributions in this area were provided by the groups of Martell [19,20], Maruoka [21,22], Wuest [4,23-25], and others [26-46]. In the majority of cases where bimetallic complexes are used as the catalytically active species, the two metal centers perform different functions $[47,48]$.

Efforts toward synthesizing bisoxazoline ligands capable of concurrently binding to two metal centers have been rather limited. Previous work by Pfaltz, Fahrni, Tsukada, BelleminLaponnaz and our group resulted in the synthesis of bisoxazoline containing ligands 6-13 that can simultaneously bind to two metals (Figure 2). For instance, treatment of $\mathbf{6}$ with two equivalents of copper perchlorate hexahydrate led to the formation of a bis-copper complex $[49,50]$. The two $\mathrm{Cu}$ (II) ions, which have a $\mathrm{Cu} \cdots \mathrm{Cu}$ distance of $2.947 \AA$, are coordinated to the pentadentate bisoxazoline-imidazole moiety and are bridged by the central phenoxy group in addition to a hydroxide ligand. Ligand 7 forms complex binuclear complexes with $\mathrm{ZnCl}_{2}$ and $\mathrm{NiCl}_{2}$ involving two metal centers and three ligand units. The 2:3 $\mathrm{ZnCl}_{2} / 7$ complex crystal structure exhibits a $\mathrm{Zn} \cdots \mathrm{Zn}$ distance of $3.056 \AA$. Compound 8a forms 2:2 complexes with $\mathrm{ZnCl}_{2}$ and $\mathrm{NiCl}_{2}$, whereas $\mathbf{8 b}$ was reported to form a bis-palladium complex with one equivalent of $\left[\left(\eta^{3}-\mathrm{C}_{3} \mathrm{H}_{3}\right) \mathrm{PdCl}\right]_{2}$ [51]. Little is known about the complexing abilities of compounds 9 and 11 [49,52]. The naphthyridine-based ligand $\mathbf{1 0}$ forms a dinuclear complex with nickel(II) acetate $(\mathrm{Ni} \cdots \mathrm{Ni}$ distance $=$ $3.132 \AA$ ). Compound 12, possessing an urea backbone, forms a bis-copper complex with two equivalents of $\mathrm{CuCl}_{2}(\mathrm{Cu} \cdots \mathrm{Cu}$ distance $=4.291 \AA$ ) [53]. Tetraoxazoline ligand $\mathbf{1 3}$ undergoes formation of dinuclear complexes upon treatment with two equivalents of either $\mathrm{ZnCl}_{2}, \mathrm{Ni}\left(\mathrm{PPh}_{3}\right)_{2} \mathrm{Br}_{2}$, or $\mathrm{Cu}(\mathrm{OAc})_{2}$ (metal distances: $\mathrm{Zn} \cdots \mathrm{Zn}=8.963 \AA$; $\mathrm{Ni} \cdots \mathrm{Ni}=11.341 \AA ; \mathrm{Cu} \cdots \mathrm{Cu}=$ $9.432 \AA)$ [54].

\section{Results and Discussion}

A number of bisoxazoline ligands with different bridging units were designed. We rationalized that the presence of three binding sites per metal center would be ideal in order to achieve the desired 1:2 ligand to metal ratio, and to prevent the potential formation of 2:2 or other higher order complexes. Variation of the bridging moiety should allow for modulation of the distance between the metal centers. An important criterion for selecting bridging units was their known ability to engage in metal-binding, along with being readily available. This led to the selection of naphthyridine, pyridazine, pyrazole, and phenol building blocks. We opted to connect these linkers to oxazolines via amide bonds. The reasoning for this was twofold. Firstly, this should provide ligands with significantly improved stabilities over for instance imine linkers. In addition, each amide moiety, upon deprotonation (a requirement for complex formation), would provide a formal negative charge on the ligand, thus resulting in increased complex stability while reducing the number of spectator anions associated with the two metals. Different combinations of five- and six-membered chelate rings were considered, as those allow for further modu-<smiles></smiles>

1 Shibasaki $[14,15]$

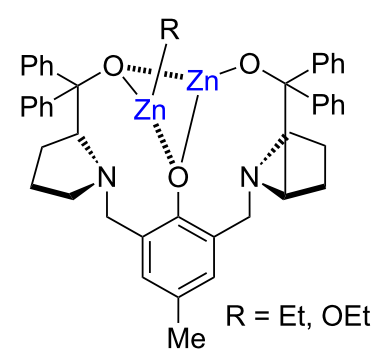

3

Trost $[17,18]$

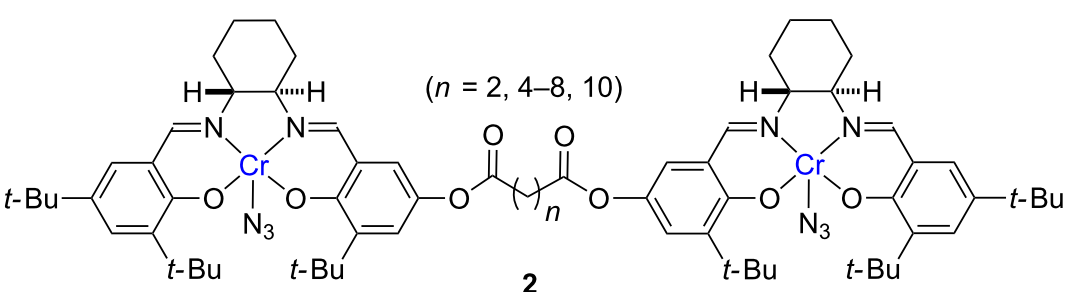

Jacobsen [16]

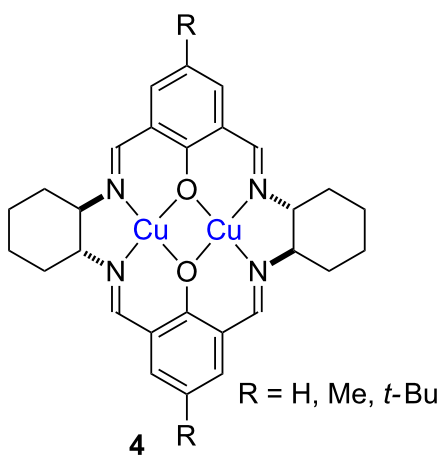

Martell $[19,20]$<smiles></smiles>

Maruoka [21] 
<smiles>Cc1cc(C)c(C2=N[C@@H](Cc3cn(C)cn3)CO2)c(O)c1C1=NC(Cc2cn(C)cn2)CO1</smiles><smiles>c1ccc(CC2COC(c3ccc4ccc(C5=N[C@@H](Cc6ccccc6)CO5)nc4n3)=N2)cc1</smiles><smiles>CC1(C)CN(c2cccc(C3=NC4c5ccccc5CC4O3)n2)C(=O)N(c2cccc(C3=N[C@@H]4c5ccccc5C[C@H]4O3)n2)C1</smiles>

12<smiles>CC(C)C1COC(c2cc(C(C)(C)C)cc(C3=NC(C(C)C)CO3)c2O)=N1</smiles><smiles>[R]C1COC(c2ccc(C3=NC([R])CO3)nn2)=N1</smiles>

$8 \mathrm{a}, \mathrm{R}=\mathrm{Bn}$

8b, $\mathrm{R}=\mathrm{iPr}$<smiles>CN(Cc1cccc(CN(C)C[C@@H]2COC(c3ccccc3)=N2)n1)CC1COC(P)=N1</smiles>

Figure 2: Previously reported bisoxazoline ligands capable of stabilizing bimetallic complexes.

lation of metal-metal distances. Convenient synthetic sequences were developed for six different ligands.

Naphthyridine-bridged bisoxazoline ligands. The synthesis of naphthyridine bridged bisoxazoline ligand $\mathbf{1 6}-\mathrm{H}_{2}$ is outlined in Scheme 1. 1,8-Naphthyridine-2,7-diacyl chloride 14, obtained via a known procedure from the corresponding diacid [49], was allowed to react with aminoindanol-derived aminophenyloxazo- line 15 [55] to provide bisoxazoline ligand $16-\mathrm{H}_{2}$ in $65 \%$ yield. Upon deprotonation, 16- $\mathrm{H}_{2}$ provides a dianionic ligand with three nitrogen donor atoms per metal center. Ligand $\mathbf{1 6}-\mathrm{H}_{2}$ was found to undergo complex formation with various copper, zinc, palladium and nickel salts.

Figure 3 shows the X-ray crystal structure of $\mathbf{1 6} \cdot \mathrm{Ni}_{2}(\mathrm{OAc})_{2}$, obtained from ligand $\mathbf{1 6}-\mathrm{H}_{2}$ and two equivalents of nickel(II)<smiles>O=C(Cl)c1ccc2ccc(C(=O)Cl)nc2n1</smiles>

14<smiles>Nc1ccccc1C1=N[C@H]2c3ccccc3C[C@H]2O1</smiles>

15<smiles>O=C(Nc1ccccc1C1=N[C@@H]2c3ccccc3C[C@H]2O1)c1ccc2ccc(C(=O)Nc3ccccc3C3=N[C@@H]4Cc5ccccc5[C@H]4O3)nc2n1</smiles>

16- $\mathrm{H}_{2}$ 
acetate. The asymmetric unit of the crystal $\mathbf{1 6} \cdot \mathrm{Ni}_{2}(\mathrm{OAc})_{2}$ contains two nickel(II) centers held in close proximity by three donor nitrogen atoms per metal center and two differently bridged acetate ions inside the coordination sphere. The nitrogen atoms on the naphthyridine and amide moieties bind to the nickel(II) center to form a five-membered metallacycle, subtending $\mathrm{N}(2)-\mathrm{Ni}(1)-\mathrm{N}(3)$ and $\mathrm{N}(5)-\mathrm{Ni}(2)-\mathrm{N}(6)$ angles of $81.53^{\circ}$ and $80.34^{\circ}$, respectively. Additionally, the nitrogen atoms on the oxazoline and amide moieties form six-membered rings with the nickel(II) center with $\mathrm{N}(1)-\mathrm{Ni}(1)-\mathrm{N}(2)$ and $\mathrm{N}(4)-\mathrm{Ni}(2)-\mathrm{N}(5)$ angles of $93.03^{\circ}$ and $90.24^{\circ}$, respectively. All of the $\mathrm{Ni}-\mathrm{N}$ distances are between 2.003 and $2.129 \AA$, typical for complexes of this type [56,57]. Interestingly, while one of the two acetate ions bridge the two nickel(II) centers by binding through the two oxygens, the second acetate unit has a somewhat different binding pattern: one oxygen binds to $\mathrm{Ni}(1)$ and the other oxygen acts as the bridge between $\mathrm{Ni}(1)$ and $\mathrm{Ni}(2)$. The $\mathrm{Ni}(1) \cdots \mathrm{Ni}(2)$ distance is $3.448 \AA$, which is slightly longer than the corresponding $\mathrm{Ni} \cdots \mathrm{Ni}$ distance in the structurally related 10. The sixth coordination of $\mathrm{Ni}(2)$ is fulfilled by the amide oxygen of a second molecule of the complex (not shown in the figure for clarity). Apparently, the coordination environment involving three $\mathrm{O}$-atoms from acetate groups (the $\mathrm{Ni}(1)$ situation) for one of the two metals is preferred in $\mathbf{1 6} \cdot \mathrm{Ni}_{2}(\mathrm{OAc})_{2}$, presumably for steric reasons, as crystal packing motivations would likely favor two situations as found for $\mathrm{Ni}(2)$, and possibly favoring formation of the $1 \mathrm{D}$ polymeric chain found here extending along the crystal b-axis. When this interaction is taken into account, both the nickel(II) centers are in distorted octahedral environment. Overall, the ligand backbone of complex $\mathbf{1 6} \cdot \mathrm{Ni}_{2}(\mathrm{OAc})_{2}$ shows a helical arrangement. This helicity is facilitated by the innate stereogenic centers of the oxazoline moieties which is further extended by the flexibility afforded by the amide connections.

Naphthyridine ligand $\mathbf{2 2}-\mathrm{H}_{2}$ was designed as an analogue of ligand $16-\mathrm{H}_{2}$ that possesses a shortened amide bridge to allow for the formation of bimetallic complexes with all five-membered chelate rings. Ligand $\mathbf{2 2}-\mathrm{H}_{2}$ was obtained starting from glycinol 17 and $N$-carboxybenzyl glycine (20) via the sequence of steps outlined in Scheme 2. While X-ray quality crystals have not yet been obtained, preliminary experiments have shown that ligand $\mathbf{2 2}-\mathrm{H}_{2}$ undergoes complex formation with various nickel and palladium salts [58].

Pyrazole-bridged bisoxazoline ligands. The synthesis of an analog of bisoxazoline ligand $\mathbf{1 6}-\mathrm{H}_{2}$ in which the naphthyridine bridge is replaced with a pyrazole linker is shown in Scheme 3. In addition to the change in geometry, compound $25-\mathrm{H}_{3}$ is a potentially trianionic as opposed to a dianionic ligand. A reaction of pyrazole-3,5-diacyl chloride 23, obtained by treatment of

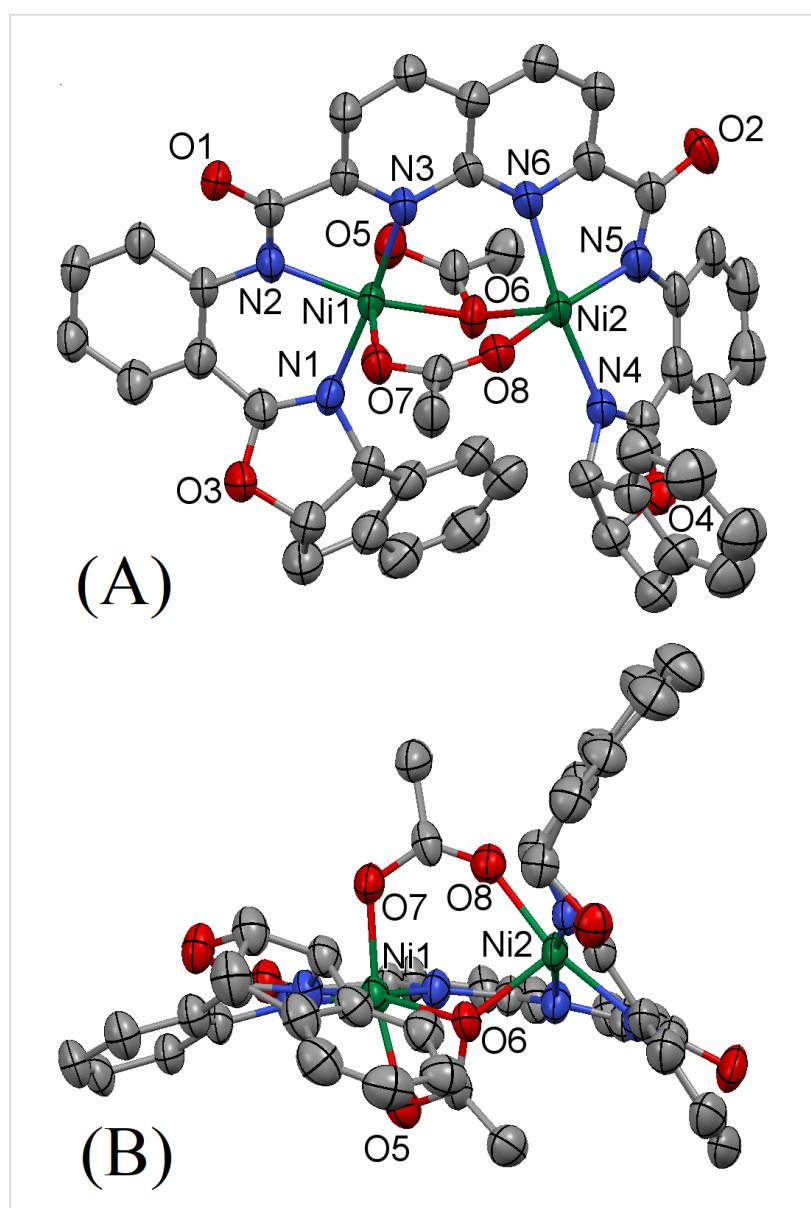

Figure 3: Thermal ellipsoid plot (50\% probability) of the molecular structure of $16 \cdot \mathrm{Ni}_{2}(\mathrm{OAc})_{2}$. Hydrogen and solvate atoms have been omitted for clarity: (A) view normal to the mean molecular plane; (B) side view nearly perpendicular to $(A)$ to allow better view of the region of open access to the metal site. The complex $16 \cdot \mathrm{Ni}_{2}(\mathrm{OAc})_{2}$ crystallizes in the orthorhombic space group $P 2{ }_{1} 2{ }_{1} 2{ }_{1}$ with $a=14.1829(5) \AA, b=14.8645(6) \AA, c=25.2342(10) \AA, \alpha=90^{\circ}$, $\beta=90^{\circ}, \gamma=90^{\circ}, V=5319.9(4) \AA^{3}, Z=4, D_{c}=1.450 \mathrm{mg} \mathrm{m}^{-3}$ and $\mu($ Mo Ka $)=1.017 \mathrm{~mm}^{-1}$.

pyrazol-3,5-dicarboxylic acid with thionyl chloride, with aminophenyloxazoline 24 [59] provided ligand $25-\mathrm{H}_{3}$ in $85 \%$ yield.

Treatment of $25-\mathrm{H}_{3}$ with nickel(II) acetate provided the binuclear complex $\mathbf{2 5} \cdot \mathrm{Ni}_{2}(\mathrm{OAc})$, the X-ray structure of which is shown in Figure 4. Each unit of the complex is comprised of two nickel(II) centers, each bound by three nitrogen atoms from the ligand skeleton and bridged by an acetate anion. The nitrogen atoms from pyrazole and amide moieties coordinate to the two nickel centers to form five-membered metallacycles, subtending $\mathrm{N}(1)-\mathrm{Ni}(1)-\mathrm{N}(2)$ and $\mathrm{N}(4)-\mathrm{Ni}(2)-\mathrm{N}(5)$ angles of $84.0^{\circ}$ and $85.0^{\circ}$, respectively. Similarly, the nitrogen atoms on amide and oxazoline moieties form six-membered metallacyles with the two metal centers, with $\mathrm{N}(2)-\mathrm{Ni}(1)-\mathrm{N}(3)$ and $\mathrm{N}(5)-\mathrm{Ni}(2)-\mathrm{N}(6)$ angles of $92.63^{\circ}$ and $94.33^{\circ}$, respectively. All 


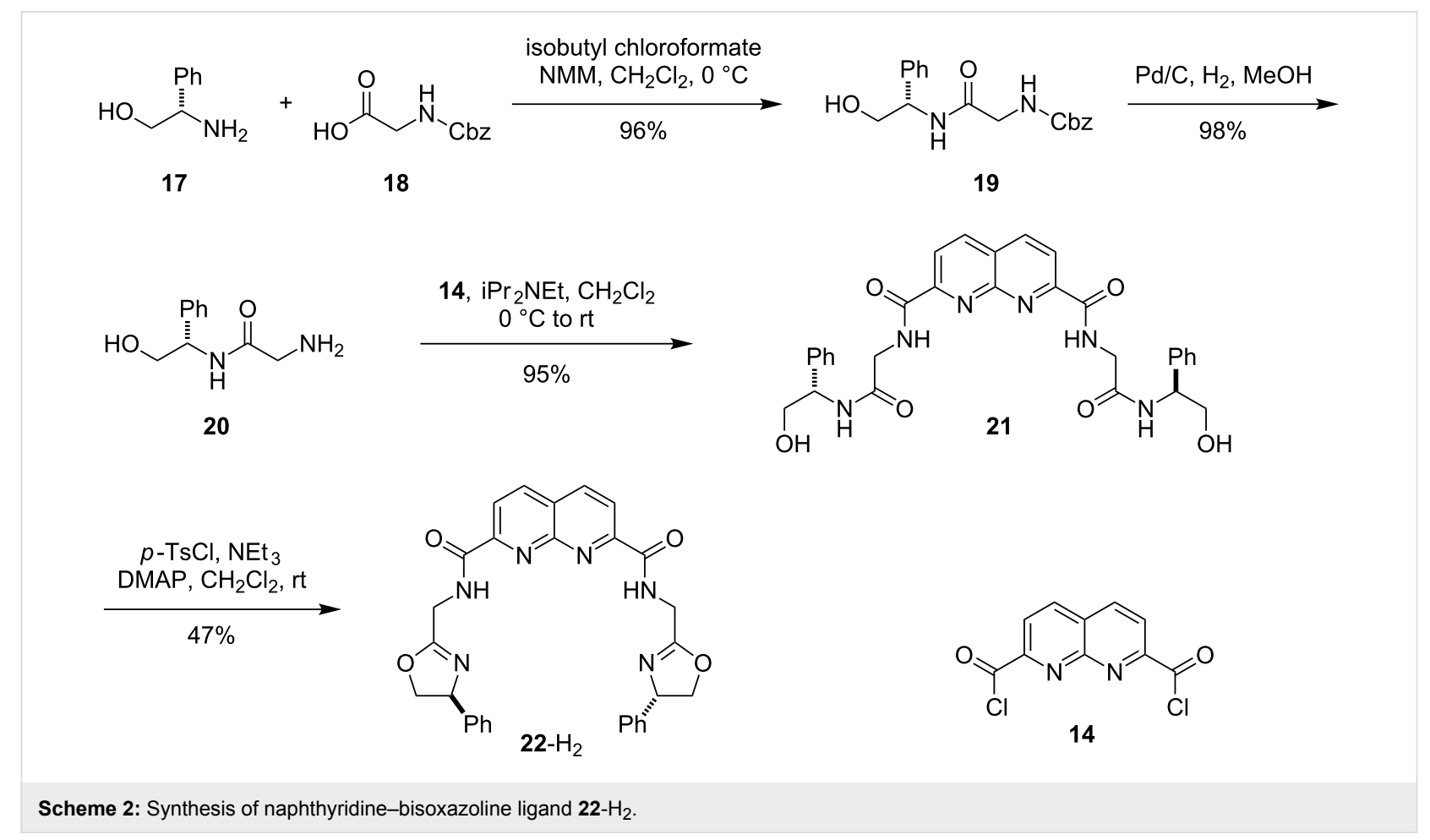

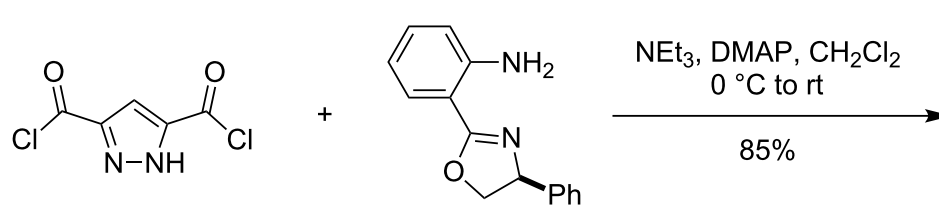

23

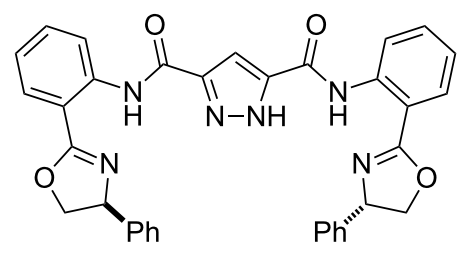

$25-\mathrm{H}_{3}$

Scheme 3: Synthesis of pyrazole-bisoxazoline ligand $25-\mathrm{H}_{3}$.

the $\mathrm{Ni}-\mathrm{N}$ distances are between 1.855 and $1.903 \AA$, typical for $\mathrm{Ni}-\mathrm{N}$ bonds having this coordination geometry. The two nickel centers are bridged by an acetate ion and the pyrazole segment of the ligand, with a distorted square planar geometry observed for both metal centers. The resulting $\mathrm{Ni}(1) \cdots \mathrm{Ni}(2)$ distance is $4.176 \AA$ A.

The synthesis of a pyrazole containing ligand potentially capable of forming bimetallic complexes with all five-membered chelate rings is shown in Scheme 4. Trianionic ligand 30- $\mathrm{H}_{3}$ was prepared starting from the $\mathrm{N}$-carboxybenzyl amino acid 26. Coupling of $\mathbf{2 6}$ with phenylglycinol (17) resulted in the formation of the amide 27. Subsequent treatment with $p$-toluenesulfonyl chloride and triethylamine in the presence of a catalytic amount of DMAP provided oxazoline 28. Following deprotection, the resulting amine $\mathbf{2 9}$ was allowed to react with half an equivalent of the pyrazole diacyl chloride $\mathbf{2 3}$ to yield the pyrazole-bridged bisoxazoline ligand $\mathbf{3 0}-\mathrm{H}_{3}$.
Initial experiments have shown that the trianionic ligand $\mathbf{3 0}-\mathrm{H}_{3}$ readily forms complexes with various nickel, copper and palladium salts. Figure 5 shows the X-ray crystal structure of 30 $\cdot \mathrm{Pd}_{2} \mathrm{Br}$, obtained from ligand $\mathbf{3 0}-\mathrm{H}_{3}$ and two equivalents of palladium(II) bromide. Each of the two palladium(II) centers of the complex $30 \cdot \mathrm{Pd}_{2} \mathrm{Br}$ is confined in a slightly distorted square planar geometry by three donor nitrogen atoms from the ligand and a bridging bromide ion. Unlike the situation in $16 \cdot \mathrm{Ni}_{2}(\mathrm{OAc})_{2}$, where the $\mathrm{Ni}-\mathrm{O}$ bond from the carbonyl of an adjacent molecule yields both the five-coordinate $\mathrm{Ni}$ and $1 \mathrm{D}$ polymeric chain, there are no $\mathrm{Pd}-\mathrm{O}$ bonds (not even dative) in 30 $\cdot \mathrm{Pd}_{2} \mathrm{Br}$ and the $\mathrm{Pd}$ atoms remain nearly square planar. The donor nitrogen atoms from pyrazole, amide and oxazoline moieties coordinate to the palladium centers, forming fivemembered chelate rings, with the subtended $\mathrm{N}-\mathrm{Pd}-\mathrm{N}$ angles ranging from $79.43^{\circ}$ to $82.16^{\circ}$. The two palladium centers are bridged by the bromide ion and the pyrazole segment. All of the $\mathrm{Pd}-\mathrm{N}$ bond lengths fall within a relatively narrow range of 

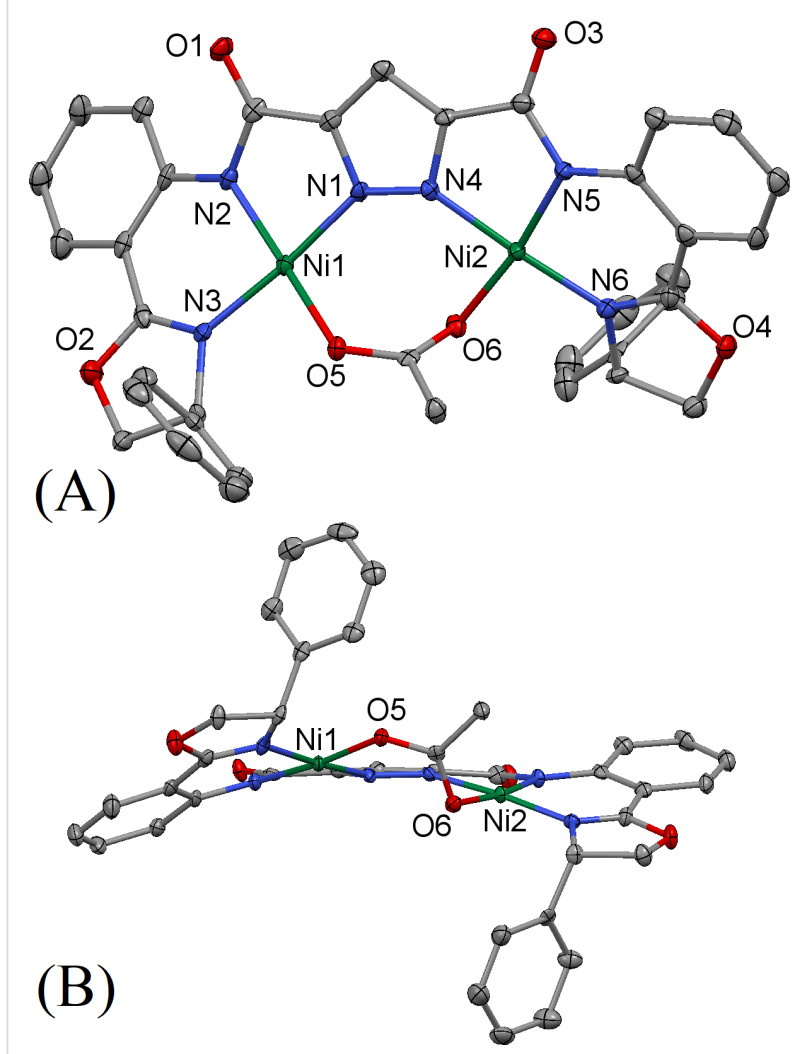

Figure 4: Thermal ellipsoid plot (50\% probability) of the molecular structure of $25 \cdot \mathrm{Ni}_{2}(\mathrm{OAc})$. Hydrogen and solvate atoms have been omitted for clarity: (A) view normal to the mean molecular plane; (B) side view nearly perpendicular to (A) to allow better view of the region of open access to the metal site. The complex $25 \cdot \mathrm{Ni}_{2}(\mathrm{OAc})$ crystallizes in the monoclinic space group $P 2{ }_{1}$ with $a=9.0473(9) \AA$, $b=17.5433(17) \AA, c=11.7671(11) \AA, \alpha=90^{\circ}, \beta=109.643(2)^{\circ}$, $y=90^{\circ}, V=1759.0(3) \AA^{3}, Z=2, D_{c}=1.614 \mathrm{mg} \mathrm{m}^{-3}$ and $\mu($ Mo Ka $)=1.281 \mathrm{~mm}^{-1}$.
1.925 to $2.025 \AA$, and are typical for $\mathrm{Pd}-\mathrm{N}$ bonds with this coordination geometry. As expected, the $\mathrm{Pd}-\mathrm{Br}$ bond lengths are slightly longer (2.519 and $2.529 \AA$ ) than the $\mathrm{Pd}-\mathrm{N}$ bonds. The bromide ion bridges the two palladium centers with a $\mathrm{Pd}-\mathrm{Br}-\mathrm{Pd}$ angle of $98.48^{\circ}$. The two nitrogen donor atoms from the pyrazole moiety forms the second bridging link between the two metal centers, thereby restricting the $\mathrm{N}(1)-\operatorname{Pd}(1)-\operatorname{Br}(1)$ and $\mathrm{N}(4)-\operatorname{Pd}(2)-\operatorname{Br}(1)$ angles to $89.89^{\circ}$ and $89.73^{\circ}$, respectively. The resulting $\operatorname{Pd}(1) \cdots \operatorname{Pd}(2)$ distance was observed to be $3.824 \AA$.

Pyridazine-bridged bisoxazoline ligands. Ligand $32-\mathrm{H}_{2}$ was synthesized from pyridazine diester 31 [60] and aminophenyloxazoline 15 (Scheme 5). Treatment of 15 with LDA, followed by addition of $\mathbf{3 1}$, resulted in the formation of the pyridazine bridged bisoxazoline ligand $\mathbf{3 2}-\mathrm{H}_{2}$.

Upon deprotonation, 32- $\mathrm{H}_{2}$ provides a dianionic ligand with three donor nitrogen atoms per metal center. Ligand $\mathbf{3 2}-\mathrm{H}_{2}$ forms complexes with different nickel, copper, zinc and palladium salts. Shown in Figure 6 is the molecular structure of $32 \cdot \mathrm{Zn}_{2} \mathrm{Cl}_{2}$. Each unit of the complex $32 \cdot \mathrm{Zn}_{2} \mathrm{Cl}_{2}$ consists of two zinc(II) centers, with each bound by three donor nitrogen atoms from the ligand skeleton and bridged by a chloride ion. The nitrogen atoms on the pyridazine and amide moieties form fivemembered chelate rings upon coordination to the zinc centers, subtending $\mathrm{N}(2)-\mathrm{Zn}(1)-\mathrm{N}(1)$ and $\mathrm{N}(5)-\mathrm{Zn}(2)-\mathrm{N}(4)$ angles of $74.74^{\circ}$ and $77.04^{\circ}$, respectively. The coordination of the nitrogen atoms on oxazoline and amide moieties with the two zinc centers forms six-membered rings with $\mathrm{N}(3)-\mathrm{Zn}(1)-\mathrm{N}(2)$ and $\mathrm{N}(6)-\mathrm{Zn}(2)-\mathrm{N}(5)$ angles of $87.05^{\circ}$ and $88.55^{\circ}$, respectively. All of the $\mathrm{Zn}-\mathrm{N}$ distances are within 2.023-2.177 $\AA$, as expected for such complexes. Interestingly, the two chloride ions

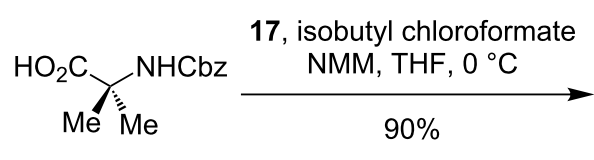

26

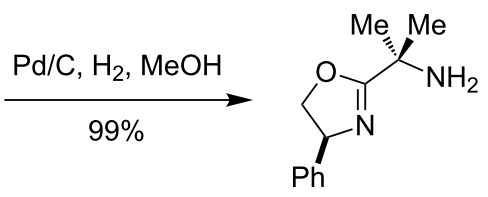

29<smiles>O=C(O)NC([O-])(C(=O)NC(CO)c1ccccc1)[N+](=O)[O-]</smiles>

27

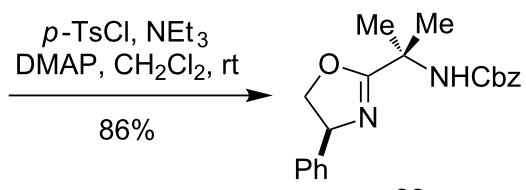

28 

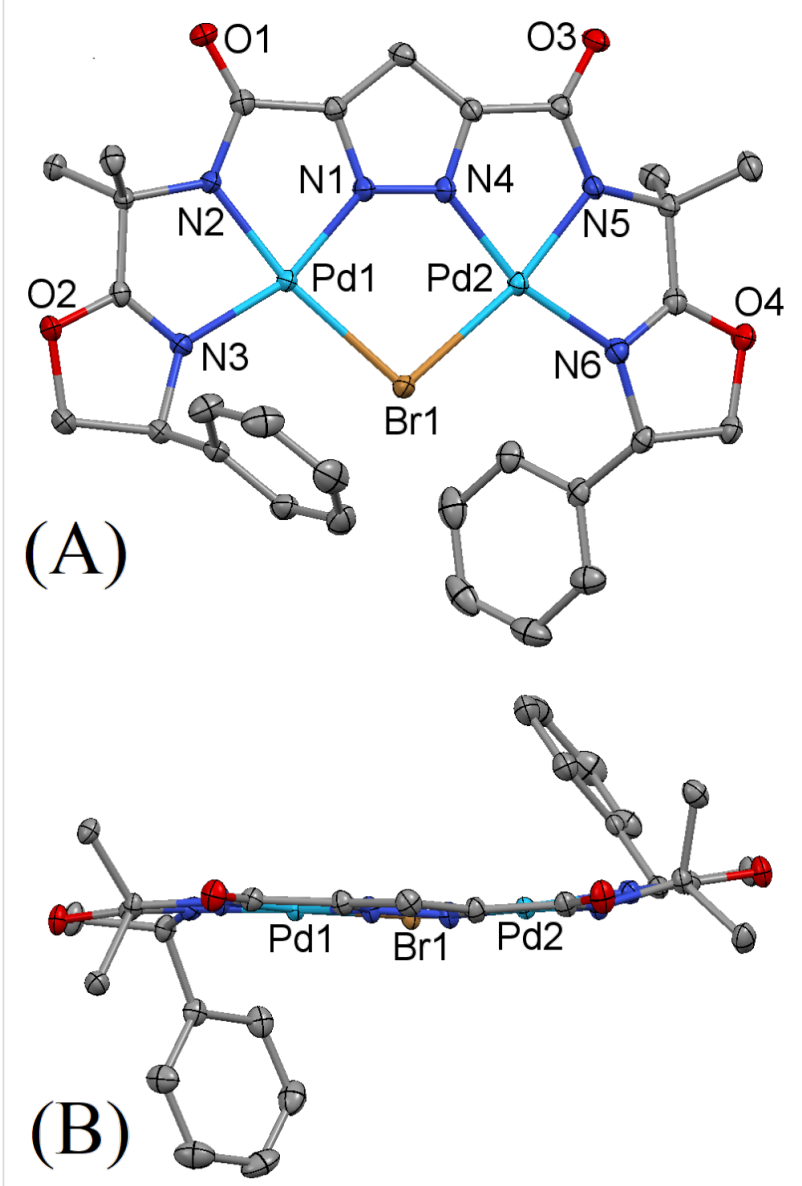

Figure 5: Thermal ellipsoid plot (50\% probability) of the molecular structure of $30 \cdot \mathrm{Pd}_{2} \mathrm{Br}$. Hydrogen and solvate atoms have been omitted for clarity: $(A)$ view normal to the mean molecular plane; $(B)$ side view nearly perpendicular to $(A)$ to allow a better view of the region of open access to the metal site. The complex $30 \cdot \mathrm{Pd}_{2} \mathrm{Br}$ crystallizes in the monoclinic space group $P 2_{1}$ with $a=9.8982(7) \AA, b=10.0139(7) \AA$, $c=16.9675(12) \AA, \alpha=90^{\circ}, \beta=101.277(1)^{\circ}, \gamma=90^{\circ}, V=1649.3(2) \AA^{3}$ $Z=2, D_{c}=1.847 \mathrm{mg} \mathrm{m}^{-3}$ and $\mu(\mathrm{Mo} \mathrm{Ka})=2.510 \mathrm{~mm}^{-1}$.

bind in discrete manners. While one of them acts as a bridge between the two zinc centers with a $\mathrm{Zn}(1)-\mathrm{Cl}(1)-\mathrm{Zn}(2)$ angle of $105.97^{\circ}$, the other chloride ion binds to $\mathrm{Zn}(2)$ only with a
$\mathrm{Zn}(2)-\mathrm{Cl}(2)$ distance of $2.241 \AA$. Consistent with having a bridging chloride atom, the $\mathrm{Zn}(1) \cdots \mathrm{Zn}(2)$ distance of $3.857 \AA$ is somewhat long, compared to the $\mathrm{M} \cdots \mathrm{M}$ distances in two of the crystal structures mentioned here, namely, the $\mathrm{Ni} \cdots \mathrm{Ni}$ in $\mathbf{1 6} \cdot \mathrm{Ni}_{2}(\mathrm{OAc})_{2}$ at $3.338 \AA$, shorter because of the smaller radius of the bridging $\mu_{2}-\mathrm{O}$ atom, and the $\mathbf{3 0} \cdot \mathrm{Pd}_{2} \mathrm{Br}$ at $3.824 \AA$, shorter because of both the $\mathrm{Pd}$ coordination geometry and the bridging $\mu_{2}-\mathrm{Br}$ atom. The $\mathrm{Ni} \cdots \mathrm{Ni}$ in $\mathbf{2 5} \cdot \mathrm{Ni}_{2}(\mathrm{OAc})$ at $4.176 \AA$ is longer due to its longer three-atom bridge from OAc. In the Cambridge Structural Database (CSD), there are ten instances of $\mathrm{Ni}-\mathrm{N}-\mathrm{N}-\mathrm{Ni}$ bond connectivity with $\mathrm{sp}^{2} \mathrm{~N}$-atoms that are also bonded to a $\mathrm{C}$-atom. However, all of those have trans related $\mathrm{Ni}$ atoms unlike the cis related here such that the $\mathrm{Ni} \cdots \mathrm{Ni}$ distances range from 4.54 to $4.72 \AA$ for those ten compounds. Similarly, for $\mathrm{Pd}-\mathrm{N}-\mathrm{N}-\mathrm{Pd}$ and $\mathrm{Zn}-\mathrm{N}-\mathrm{N}-\mathrm{Zn}$, there are few and only all trans situations in the CSD with ranges of 4.83 to $4.84 \AA$ and 4.53 to $4.78 \AA$, respectively, for the two Pd and three $\mathrm{Zn}$ compounds. For $\mathrm{M}-\mathrm{N}-\mathrm{N}-\mathrm{M}$ with $\mathrm{sp}^{3}$ bridging $\mathrm{N}$-atoms, only four instances are found - all with $\mathrm{M}=\mathrm{Zn}$ and $\mathrm{N}-\mathrm{N}$ from substituted aminohydrazido ligands and the distances are longer (4.93 to $5.04 \AA$ ) and the trans relationship maintains. Thus, the cis $\mathrm{M}-\mathrm{N}-\mathrm{N}-\mathrm{M}$ geometry observed here is quite rare for $\mathrm{M}=\mathrm{Ni}$, $\mathrm{Zn}, \mathrm{Pd}$ and is uncommon for $\mathrm{M}=$ any transition metal (about 90 instances in CSD). Different coordination environments are found for $\mathrm{Zn}(1)$ and $\mathrm{Zn}(2)$ in $\mathbf{3 2} \cdot \mathrm{Zn}_{2} \mathrm{Cl}_{2} \cdot \mathrm{Zn}(1)$ is found to exist in a square planar environment that experiences a significant tetrahedral distortion. In contrast, a distorted square pyramidal binding mode is observed for $\mathrm{Zn}(2)$.

Phenol-bridged bisoxazoline ligands. Ligands incorporating naphthyridine, pyridazine and pyrazole linkers discussed thus far bridge two metal atoms by attachment to two different nitrogen donor atoms. As a result, metal $\cdots$ metal distances tend to be relatively long. Ligand $\mathbf{3 4}-\mathrm{H}_{3}$ was designed to explore the effect of a single atom linker, namely a phenoxy bridge. The tert-butyl group in the para-position was incorporated as it would likely increase the overall solubility of the ligand as well as its associated complexes. DCC-mediated coupling of 33 [49] with two equivalents of aminophenyloxazoline $\mathbf{1 5}$ led to the for-<smiles>CCOC(=O)c1ccc(C(=O)OCC)nn1</smiles>

$$
31
$$$$
15
$$

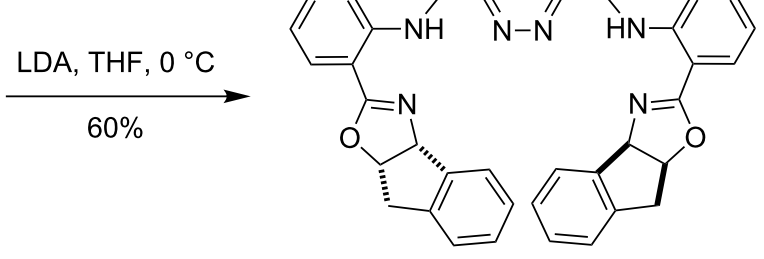

$32-\mathrm{H}_{2}$ 


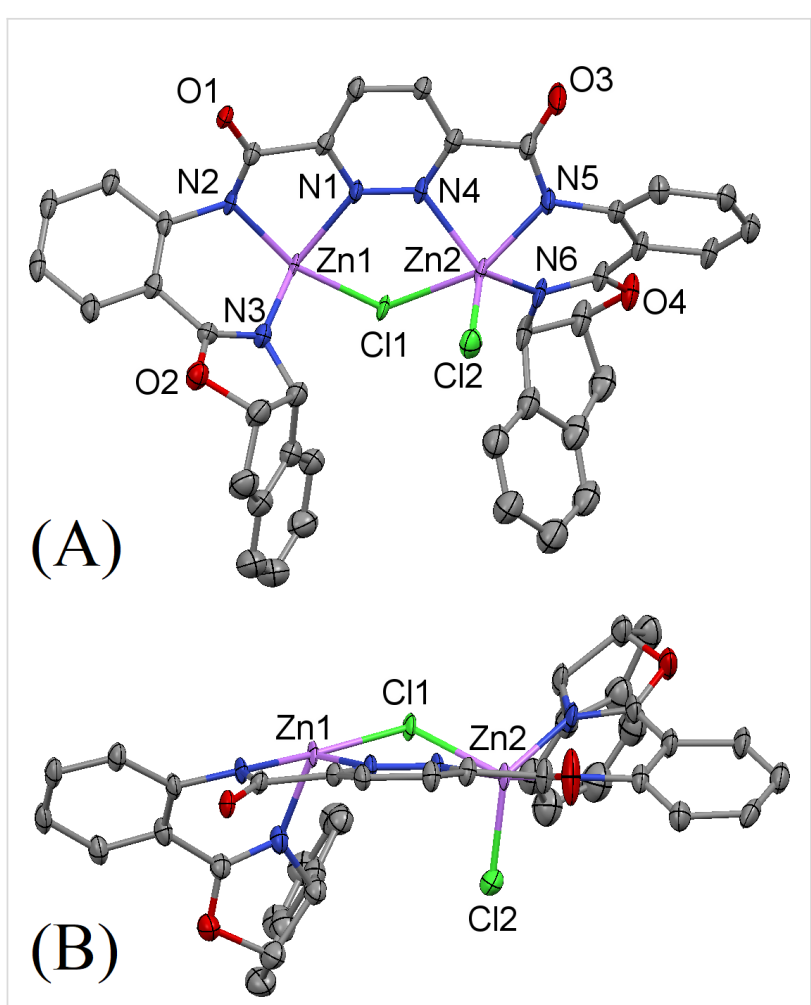

Figure 6: Thermal ellipsoid plot (50\% probability) of the molecular structure of $32 \cdot \mathrm{Zn}_{2} \mathrm{Cl}_{2}$. Hydrogen and solvate atoms have been omitted for clarity: (A) view normal to the mean molecular plane; (B) side view nearly perpendicular to (A) to allow better view of the region of open access to the metal site. The complex $32 \cdot \mathrm{Zn}_{2} \mathrm{Cl}_{2}$ crystallizes in the monoclinic space group $C_{2}$ with $a=40.820(5) \AA$, $b=7.4084(9) \AA, c=14.6489(17) \AA, \alpha=90^{\circ}, \beta=108.589(2)^{\circ}, \gamma=90^{\circ}$, $V=4189.8(9) \AA^{3}, Z=4, D_{c}=1.575 \mathrm{mg} \mathrm{m}^{-3}$ and $\mu(\mathrm{Mo} \mathrm{K \alpha})=$ $1.453 \mathrm{~mm}^{-1}$.

mation of phenol-bridged bisoxazoline ligand $34-\mathrm{H}_{3}$ in a single step and moderate yield (Scheme 6). While X-ray quality crystals have not yet been obtained, preliminary experiments have shown that ligand $\mathbf{3 4}-\mathrm{H}_{2}$ forms complexes with nickel, copper and palladium salts [58].

\section{Conclusion}

We have achieved the synthesis of chiral bisoxazoline ligands that incorporate naphthyridine, pyrazole, pyridazine and phenol bridges. These compounds readily form complexes with various transition metal salts and may provide a platform for the development of new catalytic enantioselective transformations.

\section{Supporting Information}

\section{Supporting Information File 1}

Experimental procedures and characterization data.

[https://www.beilstein-journals.org/bjoc/content/ supplementary/1860-5397-14-175-S1.pdf]

\section{Supporting Information File 2}

Crystallographic information files of synthesized complexes (CCDC 1568876-1568879).

[https://www.beilstein-journals.org/bjoc/content/ supplementary/1860-5397-14-175-S2.zip]

\section{Acknowledgements}

Acknowledgement is made to the Donors of the American Chemical Society Petroleum Research Fund for support of this research (Grant No. 47698-G1). We thank Dr. Jacob M. Janey (formerly Merck \& Co.) for a generous donation of cis-1amino-2-indanol.

\section{ORCID ${ }^{\circledR}$ iDs}

Daniel Seidel - https://orcid.org/0000-0001-6725-111X

\section{References}

1. Johnson, J. S.; Evans, D. A. Acc. Chem. Res. 2000, 33, 325. doi:10.1021/ar960062n

2. McManus, H. A.; Guiry, P. J. Chem. Rev. 2004, 104, 4151 doi:10.1021/cr040642v<smiles>CC(C)(C)c1cc(C(=O)O)c(O)c(C(=O)O)c1</smiles>

33<smiles>Nc1ccccc1C1=N[C@H]2c3ccccc3C[C@H]2O1</smiles>

15<smiles></smiles>

$34-\mathrm{H}_{3}$ 
3. Desimoni, G.; Faita, G.; Jorgensen, K. A. Chem. Rev. 2006, 106, 3561. doi:10.1021/cr0505324

4. Vaugeois, J.; Simard, M.; Wuest, J. D. Coord. Chem. Rev. 1995, 145, 55. doi:10.1016/0010-8545(95)90216-3

5. Gavrilova, A. L.; Bosnich, B. Chem. Rev. 2004, 104, 349. doi:10.1021/cr020604g

6. Shibasaki, M.; Yamamoto, Y., Eds. Multimetallic Catalysts in Organic Synthesis; Wiley-VCH: Weinheim, 2004.

7. Mitić, N.; Smith, S. J.; Neves, A.; Guddat, L. W.; Gahan, L. R.; Schenk, G. Chem. Rev. 2006, 106, 3338. doi:10.1021/cr050318f

8. Karplus, P. A.; Pearson, M. A.; Hausinger, R. P. Acc. Chem. Res. 1997, 30, 330. doi:10.1021/ar960022j

9. Stenkamp, R. E. Chem. Rev. 1994, 94, 715. doi:10.1021/cr00027a008

10. Whittington, D. A.; Lippard, S. J. J. Am. Chem. Soc. 2001, 123, 827. doi:10.1021/ja003240n

11. Logan, D. T.; Su, X.-D.; Åberg, A.; Regnström, K.; Hajdu, J.; Eklund, H.; Nordlund, P. Structure 1996, 4, 1053. doi:10.1016/S0969-2126(96)00112-8

12. Gerdemann, C.; Eicken, C.; Krebs, B. Acc. Chem. Res. 2002, 35, 183. doi:10.1021/ar990019a

13. Kanyo, Z. F.; Scolnick, L. R.; Ash, D. E.; Christianson, D. W. Nature 1996, 383, 554. doi:10.1038/383554a0

14. Shibasaki, M.; Sasai, H.; Arai, T. Angew. Chem., Int. Ed. Engl. 1997, 36, 1237. doi:10.1002/anie.199712361

15. Shibasaki, M.; Kanai, M.; Matsunaga, S.; Kumagai, N. Acc. Chem. Res. 2009, 42, 1117. doi:10.1021/ar9000108

16. Konsler, R. G.; Karl, J.; Jacobsen, E. N. J. Am. Chem. Soc. 1998, 120 , 10780. doi:10.1021/ja982683c

17. Trost, B. M.; Ito, H. J. Am. Chem. Soc. 2000, 122, 12003. doi:10.1021/ja003033n

18. Trost, B. M.; Bartlett, M. J. Acc. Chem. Res. 2015, 48, 688. doi:10.1021/ar500374r

19. Gao, J.; Reibenspies, J. H.; Martell, A. E. Angew. Chem., Int. Ed. 2003, 42, 6008. doi:10.1002/anie.200351978

20. Gao, J.; Zingaro, R. A.; Reibenspies, J. H.; Martell, A. E. Org. Lett. 2004, 6, 2453. doi:10.1021/ol049156k

21. Ooi, T.; Saito, A.; Maruoka, K. Tetrahedron Lett. 1998, 39, 3745. doi:10.1016/S0040-4039(98)00575-9

22. Keiji, M. Bull. Chem. Soc. Jpn. 2009, 82, 917. doi:10.1246/bcsj.82.917

23. Sharma, V.; Simard, M.; Wuest, J. D. J. Am. Chem. Soc. 1992, 114, 7931. doi:10.1021/ja00046a061

24. Vaugeois, J.; Wuest, J. D. J. Am. Chem. Soc. 1998, 120, 13016. doi:10.1021/ja982725x

25. Wuest, J. D. Acc. Chem. Res. 1999, 32, 81. doi:10.1021/ar980076o

26. Constable, E. C.; Zhang, G.; Housecroft, C. E.; Neuburger, M.; Schaffner, S.; Woggon, W.-D. New J. Chem. 2009, 33, 1064. doi:10.1039/b821995h

27. Tschinkl, M.; Schier, A.; Riede, J.; Gabbai, F. P. Organometallics 1999, 18, 1747. doi:10.1021/om990144q

28. Guo, Q.-X.; Wu, Z.-J.; Luo, Z.-B.; Liu, Q.-Z.; Ye, J.-L.; Luo, S.-W.; Cun, L.-F.; Gong, L.-Z. J. Am. Chem. Soc. 2007, 129, 13927. doi:10.1021/ja074322f

29. Park, J.; Lang, K.; Abboud, K. A.; Hong, S. J. Am. Chem. Soc. 2008, 130, 16484. doi:10.1021/ja807221s

30. Li, W.; Thakur, S. S.; Chen, S.-W.; Shin, C.-K.; Kawthekar, R. B.; Kim, G.-J. Tetrahedron Lett. 2006, 47, 3453. doi:10.1016/j.tetlet.2006.03.042

31. Kawthekar, R. B.; Kim, G.-J. Helv. Chim. Acta 2008, 91, 317. doi:10.1002/hlca.200890037
32. Annamalai, V.; DiMauro, E. F.; Carroll, P. J.; Kozlowski, M. C. J. Org. Chem. 2003, 68, 1973. doi:10.1021/jo025993t

33. Prokofieva, A.; Dechert, S.; Grosse, C.; Sheldrick, G. M.; Meyer, F. Chem. - Eur. J. 2009, 15, 4994. doi:10.1002/chem.200900424

34. Oh, T.; Lopez, P.; Reilly, M. Eur. J. Org. Chem. 2000, 2901. doi:10.1002/1099-0690(200008)2000:16<2901::AID-EJOC2901>3.0.C O;2-0

35. Reilly, M.; Oh, T. Tetrahedron Lett. 1995, 36, 221. doi:10.1016/0040-4039(94)02227-3

36. Jammi, S.; Saha, P.; Sanyashi, S.; Sakthivel, S.; Punniyamurthy, T. Tetrahedron 2008, 64, 11724. doi:10.1016/j.tet.2008.10.009

37. Keller, F.; Rippert, A. J. Helv. Chim. Acta 1999, 82, 125. doi:10.1002/(SICI)1522-2675(19990113)82:1<125::AID-HLCA125>3.0. CO;2-W

38. Takizawa, S.; Katayama, T.; Sasai, H. Chem. Commun. 2008, 4113. doi:10.1039/b806016a

39. Takizawa, S.; Katayama, T.; Somei, H.; Asano, Y.; Yoshida, T.; Kameyama, C.; Rajesh, D.; Onitsuka, K.; Suzuki, T.; Mikami, M.; Yamataka, H.; Jayaprakash, D.; Sasai, H. Tetrahedron 2008, 64, 3361. doi:10.1016/j.tet.2008.01.110

40. Saito, A.; Yanai, H.; Taguchi, T. Tetrahedron Lett. 2004, 45, 9439. doi:10.1016/j.tetlet.2004.10.079

41. Saito, A.; Ito, H.; Taguchi, T. Org. Lett. 2002, 4, 4619. doi:10.1021/ol026963f

42. Kleinbeck, F.; Toste, F. D. J. Am. Chem. Soc. 2009, 131, 9178. doi:10.1021/ja904055z

43. Zhao, D.; Yuan, Y.; Chan, A. S. C.; Wang, R. Chem. - Eur. J. 2009, 15, 2738. doi:10.1002/chem.200802688

44. Sun, J.; Yang, M.; Yuan, F.; Jia, X.; Yang, X.; Pan, Y.; Zhu, C. Adv. Synth. Catal. 2009, 351, 920. doi:10.1002/adsc.200800767

45. Sun, J.; Yuan, F.; Yang, M.; Pan, Y.; Zhu, C. Tetrahedron Lett. 2009, 50, 548. doi:10.1016/j.tetlet.2008.11.060

46. Sakaguchi, S.; Yoo, K. S.; O'Neil, J.; Lee, J. H.; Stewart, T.; Jung, K. W. Angew. Chem., Int. Ed. 2008, 47, 9326. doi:10.1002/anie. 200803793

47. Ma, J.-A.; Cahard, D. Angew. Chem., Int. Ed. 2004, 43, 4566. doi:10.1002/anie.200300635

48. Park, J.; Hong, S. Chem. Soc. Rev. 2012, 41, 6931. doi:10.1039/c2cs35129c

49. Fahrni, C. J.; Pfaltz, A. Helv. Chim. Acta 1998, 81, 491. doi:10.1002/hlca.19980810304

50. Fahrni, C. J.; Pfaltz, A.; Neuburger, M.; Zehnder, M. Helv. Chim. Acta 1998, 81, 507. doi:10.1002/hlca.19980810305

51. Tsukada, N.; Sato, T.; Mori, H.; Sugawara, S.; Kabuto, C.; Miyano, S.; Inoue, Y. J. Organomet. Chem. 2001, 627, 121. doi:10.1016/S0022-328X(01)00729-X

52. Seitz, M.; Kaiser, A.; Tereshchenko, A.; Geiger, C.; Uematsu, Y.; Reiser, O. Tetrahedron 2006, 62, 9973. doi:10.1016/j.tet.2006.08.003

53. Mal, R.; Mittal, N.; Emge, T. J.; Seidel, D. Chem. Commun. 2009, 7309 doi:10.1039/b918735a

54. Nano, A.; Brelot, L.; Rogez, G.; Maisse-François, A.; Bellemin-Laponnaz, S. Inorg. Chim. Acta 2011, 376, 285. doi:10.1016/j.ica.2011.06.029

55. Doherty, S.; Knight, J. G.; McRae, A.; Harrington, R. W.; Clegg, W. Eur. J. Org. Chem. 2008, 1759. doi:10.1002/ejoc.200700922

56. Allen, F. H. Acta Crystallogr., Sect. B: Struct. Sci. 2002, 58, 380. doi:10.1107/S0108768102003890

57. Groom, C. R.; Bruno, I. J.; Lightfoot, M. P.; Ward, S. C. Acta Crystallogr., Sect. B: Struct. Sci., Cryst. Eng. Mater. 2016, 72, 171. doi:10.1107/S2052520616003954 
58. In preliminary studies regarding complex formation, metal salts were mixed with the ligand in a 2:1 ratio in dichloromethane. While the metal salts were essentially insoluble in dichloromethane, nearly homogeneous solutions resulted after stirring. Following filtration and removal of solvents, brightly colored solids were obtained as opposed to white/colorless ligands.

59. Wolińska, E. Tetrahedron: Asymmetry 2014, 25, 1478 doi:10.1016/j.tetasy.2014.10.001

60. Bessard, Y.; Crettaz, R.; Brieden, W. Method of producing pyridazine-3,6-dicarboxylic esters. WO Pat. Appl. WO2001007415A1, Feb 1, 2001.

\section{License and Terms}

This is an Open Access article under the terms of the Creative Commons Attribution License

(http://creativecommons.org/licenses/by/4.0). Please note that the reuse, redistribution and reproduction in particular requires that the authors and source are credited.

The license is subject to the Beilstein Journal of Organic Chemistry terms and conditions:

(https://www.beilstein-journals.org/bjoc)

The definitive version of this article is the electronic one which can be found at: doi:10.3762/bjoc. 14.175 